\title{
PEMANFAATAN TEKNOLOGI MODIFIKASI CUACA UNTUK REDISTRIBUSI CURAH HUJAN DALAM RANGKA TANGGAP DARURAT BANJIR DI PROVINSI DKI JAKARTA DAN SEKITARNYA
}

\author{
Tri Handoko Seto, Sutrisno, Sunu Tikno, dan F. Heru Widodo \\ UPT Hujan Buatan BPPT
}

\begin{abstract}
Intisari
Pelaksanaan operasi TMC untuk redistribusi curah hujan di Provinsi DKI Jakarta dan sekitarnya dilakukan dengan menggunakan dua metode, yaitu metode mekanisme proses lompatan (jumping process mechanism) dan metode mekanisme persaingan (competition mechanism). Metode mekanisme proses lompatan (jumping process mechanism) dilakukan dengan proses penyemaian awan (cloud seeding) menggunakan bahan semai $\mathrm{NaCl}$ yang ditaburkan ke dalam awan menggunakan pesawat terbang. Tujuannya untuk mempercepat proses hujan pada awan-awan Cumulus yang berada di daerah upwind, yang dari radar terpantau bergerak masuk ke arah wilayah Jakarta. Sementara itu, metode mekanisme persaingan (competition mechanism) dilakukan dengan cara membakar bahan semai dalam flare menggunakan wahana penyemaian dari darat (GBG: Ground-Based Generator) yang terpasang di sejumlah lokasi di wilayah Jakarta, mulai dari hulu (daerah Puncak, Bogor) hingga hilir (sekitar Teluk Jakarta). Metode ini bertujuan untuk mengganggu mekanisme fisika awan-awan konvektif yang tumbuh di atas wilayah Jakarta dan berpotensi menjadi hujan. Secara umum, pelaksanaan TMC yang berlangsung selama 33 hari sejak tanggal 26 Januari sampai dengan 27 Februari 2013 berhasil mengurangi intensitas curah hujan dan resiko banjir di wilayah Provinsi DKI Jakarta dan sekitarnya. Selama berlangsungnya pelaksanaan TMC di Provinsi DKI Jakarta, total telah dilakukan 66 sorti penerbangan penyemaian dengan rincian 44 sorti menggunakan pesawat Hercules A-1323 dan 22 sorti menggunakan CASA 212-200 U-616. Total bahan semai $\mathrm{NaCl}$ powder yang ditaburkan sebanyak 201,8 ton, sementara dengan GBG telah melakukan pembakaran 486 batang flare di 14 lokasi, dan GBG sistem larutan di 9 lokasi masingmasing selama 158 jam. Berdasarkan data curah hujan historis dari TRMM, curah hujan aktual dari penakar dan TRMM, serta prediksi curah hujan dari GFS diperoleh hasil perhitungan pengurangan curah hujan selama operasional TMC sebesar $20-50 \%$.
\end{abstract}

\begin{abstract}
Implementation of the TMC operations for the redistribution of rainfall in Jakarta and surrounding areas is done using two methods, namely the jumping process mechanism and the competition mechanism. The jumping process mechanism performed by seeding the clouds using $\mathrm{NaCl}$ using aircraft. The goal is to accelerate the process of rain on Cumulus clouds in upwind areas, which is observed (using radar) moving in the direction to Jakarta area. Meanwhile, the competition mechanism is done by burning the material seeding in form of flares using Ground-Based Generator installed in several locations in Jakarta, ranging from upstream (Puncak area, Bogor) to downstream (around the Bay of Jakarta). This method aims to disrupt the cloud physics mechanism for the existence of convective clouds that grow in the area of Jakarta and potential rain.In general, the implementation of the TMC which lasts for 33 days from January 26 until February 27, 2013 managed to reduce the intensity of rainfall and the risk of flooding in areas of Jakarta and its surroundings. During the implementation of the TMC in Jakarta, a total of 66 flight sorties have been carried out with 44 sorties using Hercules aircraft A-1323 and 22 sorties using CASA 212-200 U-616. Total seeding material $\mathrm{NaCl}$ powder was 201.8 tons, while the Ground-Base Generators have burned 486 flares in 14 locations, and GBG solution system has operated in 9 locations for 158 hours each. Based on historical rainfall data from TRMM, actual rainfall from raingauge and TRMM, and rainfall predictions obtained by the GFS, rainfall reduction during TMC operation was about $20-50 \%$.
\end{abstract}


Kata Kunci : redistribusi curah hujan, TMC, proses lompatan, mekanisme persaingan

\section{PENDAHULUAN}

Banjir selalu menjadi permasalahan serius bagi warga yang tinggal di wilayah Jakarta dan sekitarnya (Bogor, Depok, Tangerang dan Bekasi; Jabodetabek) setiap kali musim hujan tiba. Berdasarkan catatan, kejadian banjir besar pernah melumpuhkan ibu kota Jakarta pada awal tahun 2002 dan 2007 lalu. Selain memakan korban jiwa, beberapa kerugian akibat banjir diantaranya lumpuhnya aktivitas ekonomi dan rusaknya beberapa sarana sosial serta masalah lingkungan bagi masyarakat Jabodetabek. Lebih dari itu, banjir di wilayah Jakarta juga telah mencoreng citra Kota Jakarta sebagai ibu kota Indonesia di mata dunia internasional.

Berbagai cara telah diupayakan untuk mengatasi masalah banjir di wilayah Jabodetabek, seperti misalnya pembuatan Kanal Banjir Barat, Kanal Banjir Timur, pembuatan drainase, pengerukan sungai dan situ, pelebaran sungai, dan pembuatan sistem peringatan dini. Namun demikian, permasalahan banjir tetap saja selalu melahirkan kekhawatiran masyarakat dan menjadi agenda rutin yang harus dihadapi oleh Pemerintah Daerah Provinsi DKI Jakarta, Banten dan Jawa Barat setiap kali musim hujan tiba.

Menghadapi musim hujan di wilayah Jabodetabek pada awal tahun 2013, Badan Pengkajian dan Penerapan Teknologi (BPPT) dan Badan Nasional Penanggulangan Bencana (BNPB) sejak akhir tahun 2012 telah melakukan langkah antisipatif dengan merencanakan pelaksanaan Operasi Teknologi Modifikasi Cuaca (TMC) untuk antisipasi banjir di wilayah DKI Jakarta.

Pasca kejadian banjir besar yang kembali melanda dan melumpuhkan Kota Jakarta pada tanggal 17-18 Januari 2013, Badan Meteorologi Klimatologi dan Geofisika (BMKG) memprediksi bahwa curah hujan di wilayah DKI Jakarta akan tinggi kembali pada periode tanggal 25-27 Januari 2013. Bersamaan dengan periode kejadian bulan purnama yang akan terjadi pada tanggal 27 Januari 2013, diperkirakan membuat air laut akan mengalami pasang sehingga aliran sungai sulit terbuang ke laut. Kondisi tersebut membuat kekhawatiran banyak kalangan akan terjadinya bencana banjir besar yang dapat menenggelamkan Kota Jakarta dan melumpuhkan ibu kota secara total (Kompas, 18 Januari 2013).
Menanggapi situasi tersebut, pada tanggal 18 Januari 2013 Gubernur Provinsi DKI Jakarta mengajukan Permohonan Pelaksanaan TMC Untuk Meredistibusi Curah Hujan di DKI Jakarta dan Sekitarnya kepada Kepala BNPB yang juga ditembuskan kepada Panglima TNI, Kepala BPPT dan segenap jajaran Pemerintah Daerah Provinsi DKI Jakarta.

\section{KAJIAN TEORI}

Seiring dengan penelitian yang lebih maju dalam hal teknologi modifikasi cuaca untuk mengurangi curah hujan, beberapa negara seperti China dan Rusia telah menerapkan teknologi ini untuk mencegah terjadinya hujan selama beberapa acara penting. Rusia pernah menggunakan TMC selama acara kenegaraan yang dilakukan di ruang terbuka. Sementara Cina menerapkan teknologi ini di Beijing selama upacara pembukaan Olimpiade 2008. BPPT sendiri pernah mengaplikasikan konsep TMC rain reduction di Palembang guna mengamankan wilayah Jaka Baring Sport Center dari gangguan hujan pada saat diselenggarakannya Sea Games XXVI pada bulan November tahun 2011 lalu, dan dinilai berhasil.

Penelitian tentang penurunan curah hujan telah banyak dilakukan oleh para ilmuwan di dunia, baik yang menggunakan studi laboratorium menggunakan model maupun eksperimen lapangan. Kebanyakan studi tentang penurunan curah hujan didasarkan pada hubungan antara aerosol, mikrofisika awan, dan presipitasi. Yin et al. (2000) melakukan perhitungan numerik tentang dampak penyemaian menggunakan bahan higroskopis pada pada awan konvektif. Diperoleh hasil bahwa bahan semai dengan ukuran kurang dari 2 mikron $(\mu \mathrm{m})$ bisa menurunkan presipitasi sebesar 22 - $30 \%$. Givati dan Rosenfeld (2004) menunjukkan bahwa polusi udara daerah perkotaan di California dan Israel mereduksi curah hujan tahunan sebesar $15-25 \%$. Menurut Khain et al. (2005), inti kondensasi (CCN: cloud condensation nuclei) berukuran kecil akan menghasilkan droplet yang kecil yang memiliki koefisien tumbukan yang kecil, sehingga mengakibatkan berkurangnya presipitasi pada awan-awan konvektif. 


\subsection{Mekanisme Persaingan}

Pada awal pertumbuhannya, awan tersusun atas butir-butir awan (droplets) yang berukuran sangat kecil sebanyak \pm 100 butir $/ \mathrm{cm}^{3}$ dengan ukuran butir sebesar $\pm 10 \mu \mathrm{m}$. Pada kondisi ini struktur awan sangat stabil. Sebagaimana terlihat pada Gambar 1.1, butir-butir dengan jari-jari sekitar 10 $\mu \mathrm{m}$ memiliki efisiensi tumbukan yang sangat kecil, yaitu hanya sekitar $1 \%$. Proses terjadinya presipitasi dimulai ketika butir-butir awan menjadi tidak homogen. Suplai uap air yang cukup mengakibatkan beberapa butir awan tumbuh menjadi lebih besar dari yang lainnya. Akibatnya, butir yang lebih besar tersebut memiliki kecepatan jatuh yang lebih besar dan memiliki kesempatan untuk menabrak butir-butir awan yang lebih kecil. Ketika terjadi tumbukan maka terdapat peluang terjadinya penggabungan yang semakin memperbesar butir-butir awan dengan cepat.

Pada Gambar 1, terlihat bahwa butir-butir dengan jari-jari 30 dan $40 \mu \mathrm{m}$ memiliki efisiensi tumbukan yang tinggi, yaitu sekitar $50-80 \%$. Mekanisme kunci terjadinya presipitasi pada awan konvektif adalah adanya tumbukan dan penggabungan. Jika kita menebarkan bahan semai higroskopis yang sangat halus ke dalam awan yang masih baru tumbuh maka bahan semai tersebut akan menyerap uap air dan membentuk butir-butir awan yang ukurannya sangat kecil. Semakin banyak bahan semai yang kita tebarkan maka bahan-bahan tersebut akan saling bersaing untuk memperebutkan uap air yang ada sehingga terjadi kondisi dimana ketersediaan uap air relatif menjadi berkurang terhadap keberadaan bahan higroskopis. Akibatnya, butir-butir awan sulit tumbuh menjadi lebih besar sehingga efisiensi tumbukan dalam awan sangat kecil yang menjadikan awan tetap berada dalam kondisi sangat stabil. Pada kondisi ini awan tidak akan berkembang sehingga tidak terjadi proses presipitasi.

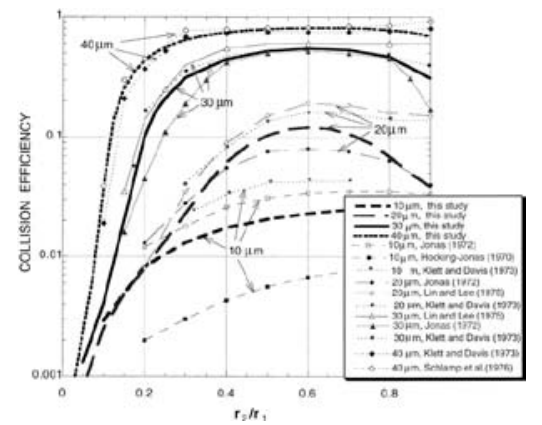

Gambar 1. Efisiensi tumbukan (Pinsky et.al., 2000).
Contoh terbaik tentang mekanisme persaingan adalah pada saat terjadi kebakaran hutan. Terdapat sangat banyak aerosol yang sangat kecil yang berada di atmosfir. Pengukuran yang dilakukan pada kasus kebakaran hutan di Kalimantan 1998 (Bruintjes et.al, 2004) memperlihatkan adanya aerosol berukuran lebih kecil dari $2 \mu \mathrm{m}$ sebanyak $\pm 2000 / \mathrm{cm}^{3}$. Kondisi ini mengakibatkan sulitnya terbentuk awan Cumulus yang aktif akibat butir-butir awan yang homogen karena banyaknya aerosol dengan ukuran yang sangat kecil. Lebih jauh Rosenfeld et.al (2008) memperlihatkan bahwa tingginya konsentrasi aerosol juga memiliki efek berupa berkurangnya radiasi matahari yang mengganggu aktifitas konveksi. Tidak perlu masuk ke dalam awan untuk menghasilkan efek kompetisi, polutan di dekat permukaan juga menghambat pertumbuhan awan.

\subsection{Mekanisme Proses Lompatan}

Sebagaimana disebutkan sebelumnya bahwa proses presipitasi terjadi akibat tingginya efisiensi tumbukan. Pada butir awan berukuran jari-jari $10 \%$ memiliki efisiensi sekitar 1\%. Jari-jari 20\% memiliki efisiensi sekitar 10\%. Ketika jari-jari mencapai ukuran $40 \mu \mathrm{m}$ maka efisiensi tumbukan meningkat hingga mencapai sekitar $80 \%$. Jelas bahwa butir awan berukuran $40 \mu \mathrm{m}$ menjadi hal penting meningkatnya aktifitas dalam awan yang mempercepat terjadinya presipitasi.
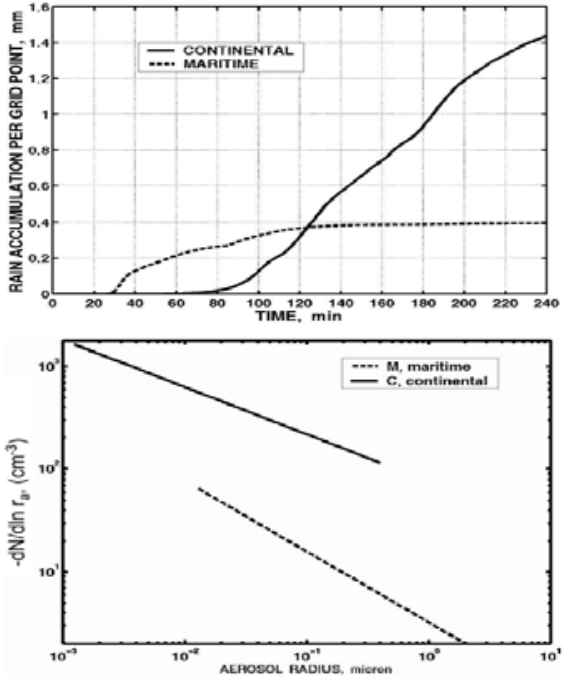

Gambar 1. Karakteristik atmosfir di atas lautan dan daratan (Khain et.al., 2005).

Pemberian bahan semai higroskopis berukuran besar pada awan yang sedang tumbuh aktif akan menghasilkan butir-butir awan berukuran besar yang akan memotong proses presipitasi menjadi lebih cepat. Ada lompatan 
yang signifikan dari proses presipitasi berupa penyediaan butir-butir awan berukuran besar yang secara drastis meningkatkan efisiensi tumbukan dalam awan.

Contoh dari mekanisme proses lompatan ini dijelaskan dengan baik oleh adanya perbedaan mendasar yang terjadi pada kondisi atmosfir di atas lautan dan daratan. Gambar 2, perbedaan atmosfir di atas lautan dan daratan adalah pada atmosfir lautan, aerosol berukuran besar tetapi jumlahnya sedikit, kelembaban tinggi, dan awanawan yang tumbuh akan cepat menjadi hujan tetapi dengan curah hujan yang sedikit; sementara pada atmosfir daratan, aerosol berukuran kecil tetapi jumlahnya banyak, kelembaban rendah, dan awan-awan yang tumbuh perlu waktu yang lama untuk menjadi hujan tetapi curah hujannya besar.

Karakteristik ini sesuai dengan Pinsky et.al., 2000 dimana aerosol berukuran besar berkorelasi dengan percepatan proses hujan. Bruintjes et.al., 2004 memperlihatkan bahwa aerosol yang berukuran sangat besar (ultra giant aerosol) dengan jari-jari lebih dari 10 mikron bisa memperpendek rangkaian proses perubahan komposisi butir awan yang menciptakan efek lompatan pada proses penggabungan.

\section{PELAKSANAAN \\ 3.1. Peralatan dan Bahan}

\subsubsection{Pesawat Terbang}

Pesawat terbang merupakan wahana pendukung utama dalam kegiatan TMC. Dalam operasi ini digunakan 2 (dua) unit pesawat yaitu 1 (satu) unit Hercules C-130 milik TNI Angkatan Udara dengan registrasi A-1323 dan 1 (satu) unit Casa 212-200 milik TNI Angkatan Laut dengan registrasi U-616. Untuk pesawat jenis Hercules dan CASA 212-200 yang digunakan telah dimodifikasi yaitu semula sebagai versi pesawat penumpang (Passenger Version) dirubah menjadi versi pesawat penyemai awan (Rain Maker Version). Pesawat Hercules C130 dan CASA 212-200 milik TNI telah dilengkapi dengan peralatan navigasi dan weather radar yang canggih, yaitu Radar Cuaca (Weather Radar) dan Global Positioning System (GPS).

\subsubsection{Bahan Semai}

Bahan semai yang digunakan adalah $\mathrm{NaCl}$ berbentuk "super fine powder" (bubuk yang berukuran sangat halus) dalam orde mikron dan bahan semai "CoSAT". Bahan semai super fine powder tersebut dalam bentuk bubuk halus yang diperoleh melalui proses panjang yang membutuhkan waktu, yaitu dari mulai tahap pengolahan di pabrik (pembakaran pada temperatur tinggi, penggilingan, dan pengemasan), hingga tahap pengiriman dari pabrik ke lokasi. Bahan semai yang digunakan pada wahana GPG berupa cairan (liquid) berupa campuran $\mathrm{CaCl}_{2}$ dengan aseton.

\subsection{Kondisi Cuaca}

Kondisi cuaca global/regional yang dominan pengaruhnya terhadap cuaca di DKI Jakarta dan sekitarnya adalah perbedaan suhu permukaan laut di Samudra Hindia bagian barat dan bagian timur yang disebut dengan IOD (Indian Ocean Dipole) serta massa udara yang datang ke wilayah DKI Jakarta dan sekitarnya. Faktor lain yang berpengaruh terhadap pembentukan awan hujan di wilayah DKI Jakarta dan sekitarnya adalah fenomena ENSO (El Nino Southern Oscilation) dan MJO (Maden Julian Oscillation) serta gangguan tropis berupa tropical depression hingga tropical cyclon yang terjadi di Samudera Hindia sebelah barat daya Sumatera hingga sebelah selatan Jawa, maupun di Samudera Hindia sebelah barat laut Australia. Sirkulasi monsun Asia-Australia, Daerah Pertemuan Angin Antar Tropis atau Inter Tropical Convergence Zone (ITCZ) yang merupakan daerah pertumbuhan awan, serta suhu permukaan laut di sekitar wilayah Indonesia juga berpengaruh terhdadap cuaca dan iklim di wilayah DKI Jakarta dan sekitarnya.

Data global/regional yang digunakan dalam menganalisis dan memprediksi kondisi cuaca di wilayah DKI Jakarta dan sekitaranya terdiri atas berbagai fenomena dengan berbagai skala temporal dan spasial. Pantauan fenomena ENSO, IOD dan MJO (Madden-Julian Oscillation) memberikan informasi mekanisme global/regional yang berpengaruh terhadap pembentukan awan dan kejadian hujan di daerah target.

ENSO dengan skala temporal antar-tahun mempengaruhi aktifitas keawanan dan hujan secara global. Sementara kondisi topografi yang bergunung di wilayah selatan DKI Jakaarta dan sekitarnya, serta dataran rendah di wilayah utara merupakan fenomena lokal yang menambah beragamnya kondisi iklim di wilayah DKI Jakarta dan sekitarnya, baik menurut ruang (wilayah) maupun waktu.

Temperatur muka laut di Pasifik equator bagian tengah hingga akhir Februari 2013 masih di kisaran normalnya. Sementara IOD di Samudera Hindia juga menunjukkan kondisi netral. Perubahan temperatur muka laut hingga akhir Februari 2013 di daerah NINO 3.4 dan IOD ditunjukkan pada Gambar 3 dan 4. 

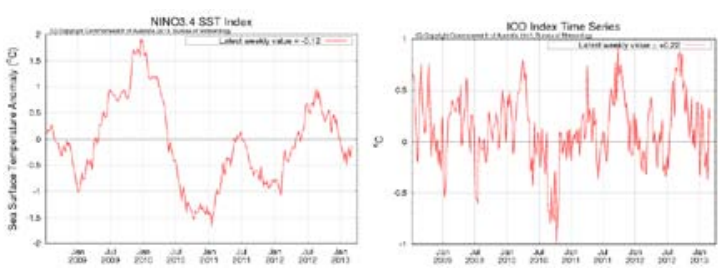

Gambar 3. Grafik Anomali SST di Nino 3.4 (kiri) dan grafik IOD Index (kanan) sampai akhir Februari 2013 yang menunjukkan kondisi ENSO netral. (Sumber: http://www.bom.gov.au /climate/enso/indices.shtml )

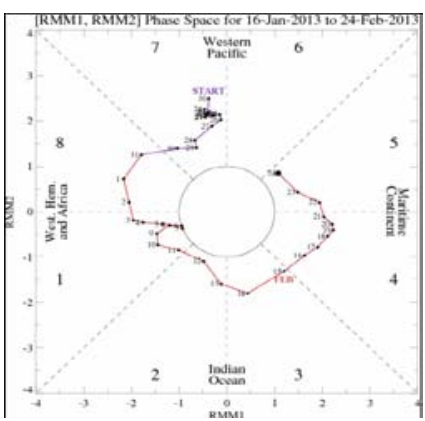

Gambar 4. Monitoring MJO periode 16 Januari 24 Februari 2013 (Sumber dari Madden-Julian Oscillation: Recent Evolution, Current Status and Prediction by Climate Prediction Center)

Selama bulan Februari 2013 , rata-rata kelembaban udara pada lapisan 850 berkisar antara 75 - 80\%. Hal ini menunjukkan bahwa secara umum kondisi atmosfer mendukung pembentukan awan hujan di daerah DKI dan sekitarnya. Pola kelembaban udara $(\mathrm{RH})$ pada lapisan $850 \mathrm{mb}$ RH bulan Februari 2013 ditunjukkan pada Gambar 5.

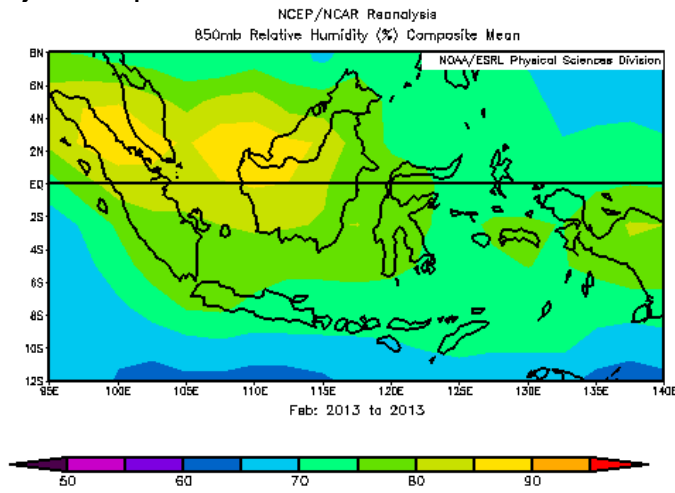

Gambar 5. Pola kelembaban udara di lapisan 850 mb pada bulan Februari 2013. (Sumber : NOAA/ESRL PSD)
Umumnya daerah Pertemuan Angin Antar Tropis atau Inter Tropical Convergence Zone (ITCZ) membentang mulai dari Sumatera, Laut Jawa hingga Nusa Tenggara. Gambar 6 daerah liputan awan dimana pertumbuhan awan cukup merata di Laut Jawa hingga Nusa Tenggara.

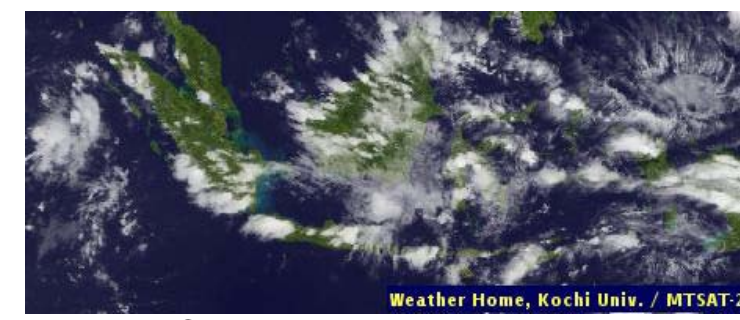

Gambar 6 Citra satelit tanggal 31 Januari 2013, jam 10:00 UTC. (Sumber: http://www.jma.go.jp/en/gms/index.ht $m l)$

Selama kegiatan TMC berlangsung angin baratan dominan di daerah target. Namun demikian terdapat pola perubahan angin dari angin baratan menjadi angin timuran yang terjadi pada tanggal 3 s.d 12 Februari 2013. Perubahan arah angin tersebut diakibatkan oleh adanya gangguan tropis berupa pusat tekanan rendah yang muncul di Samudera Hindia sebelah barat daya Ujung Kulon. Gangguan tropis berupa tropical cyclone (TC) beberapa kali muncul di Samudera Hindia sebelah selatan Jawa. Pada tanggal 15 s.d 21 Februari 2013 terdapat TC GINO di sebelah barat daya Sumatera.

Kondisi topografi sangat berpengaruh terhadap cuaca di wilayah DKI Jakarta dan sekitarnya. Variasi topografi berupa pegunungan di sebelah selatan wilayah DKI dan sekitarnya mengakibatkan pembentukan awan orografik dominan di daerah tersebut, sedangkan di bagian utara yang berupa dataran rendah didominasi oleh pembentukan awan awan konvektif. Untuk memonitor kondisi lokal dilakukan pengukuran di beberapa pos meteorologi serta pemantauan radar cuaca di wilayah DKI Jakarta dan sekitarnya.

Secara umum angin permukaan di wilayah Jakarta dan sekitarnya bertiup dari barat daya barat laut. Pada dasarian ke dua terjadi perubahan arah angin yaitu angin timur laut tenggara. Perubahan arah angin ini berhubungan dengan munculnya gangguan tropis berupa tekanan rendah di Samudera Hindia sebelah selatan Jawa bagian barat. 


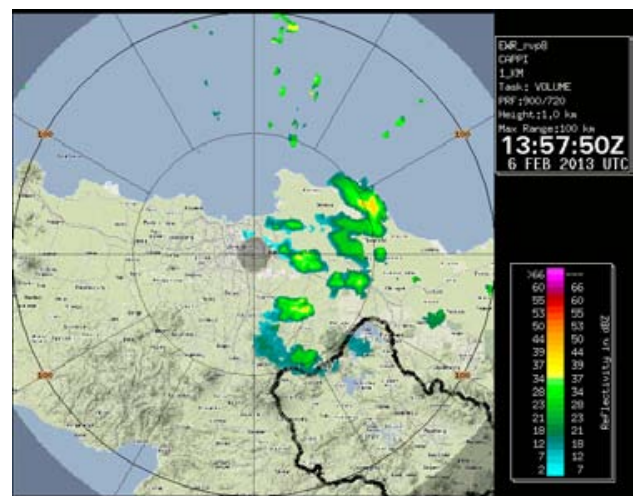

Gambar 7. Citra radar tanggal 6 Februari 2013 pukul 13.57 WIB. Terlihat kumpulan awan $\mathrm{Cb}$ yang berada di sebelah timur hingga selatan bergerak mendekati daerah DKI Jakarta dan sekitarnya.

Kondisi atmosfer dan temperatur permukaan laut yang hangat sangat mendukung pembentukan awan hujan di wilayah DKI Jakarta. Pantauan radar menunjukkan umumnya pembentukan awan konvektif berada di sebelah barat laut hingga barat daya daerah target. Sedangkan di sebelah selatan yang berupa dataran tinggi pembentukan awan lebih dominan akibat efek orografis sehingga secara klimatologis daerah tersebut relatif lebih banyak curah hujannya dibandingkan dengan di daerah lainnya. Pada saat angin timuran yang terjadi pada dasarian ke dua kegiatan TMC, awan juga banyak tumbuh di wilayah timur daerah target seperti di Karawang dan Cianjur. Contoh citra radar yang menunjukkan pembentukan awan pada tanggal 6 Februari 2013 diperlihatkan pada Gambar 7. Berdasarkan pantauan radar, pergerakan awan dari tenggara menuju barat laut.

\subsection{Operasi}

\subsubsection{Pengamatan Awan dengan Radar}

Untuk mengetahui keberadaan awan di daerah target dapat dilihat di RADAR. Radar adalah tidak lain sebuah detektor precipitation. Berapa banyak cuaca yang di kenali sangat bergantung pada rintik hujan, ukurannya, komposisi dan jumlah. Dengan adanya instrumen ini, Flight Scientist yang bertugas di lapangan dapat memperoleh informasi mengenai keberadaan dan kondisi awan yang ada di sekitar daerah target secara lebih akurat, yang tentunya sangat membantu dalam pengambilan keputusan yang berkaitan dengan misi penyemaian awan. Ada 3 (tiga) radar cuaca yang dipergunakan, 1 (satu) C-Band radar milik BMKG yang terletak di daerah Bandara Soekarno-Hatta, 1 (satu) C-Band radar milik BPPT yang terletak di Puspitek Serpong, dan 1 (satu) X-Band mobile radar milik UPT Hujan Buatan yang ditempatkan di Lanud Halim Perdanakusuma.

\subsubsection{Kegiatan Penerbangan}

Mengingat pertumbuhan awan di wilayah daerah target mulai tumbuh pada pagi menjelang siang hari, maka penerbangan pertama biasanya dilaksanakan sekitar jam 10.00 - 13.30 WIB. Penerbangan sorti kedua direncanakan sekitar jam 14.00 - 15.30 WIB. Direncanakan 4 (empat) sorti setiap hari, namun realisasinya tergantung kondisi cuaca yang setiap saat selalu berubah. Penerbangan sorti terakhir diupayakan landing tidak melebihi jam 17.30 WIB (30 menit sebelum sunset). Setiap sore jam 17.30 WIB, rencana penerbangan untuk hari berikutnya didistribusikan kepada crew pesawat, Bandara/Lanud, dan petugas di lapangan serta user. Hal ini dilakukan agar persiapan operasi hari berikutnya dapat dipersiapkan lebih awal, lebih terencana, dan lebih baik.

Daerah penyemaian dan lintasan pesawat saat melakukan penyemaian selalu direkam menggunakan alat navigasi GPS (Global Positioning System) yang dibawa oleh Flight Scientist. Pengoperasian GPS dimaksudkan untuk melihat tracking pesawat mulai onboard, saat menaburkan bahan semai, hingga pesawat kembali ke Posko, sehingga route dan manuver pesawat selama terbang terekam dengan baik. Pengoperasian GPS dilakukan oleh Flight Scientist selama penerbangan eksekusi.

Pada periode pelaksanaan TMC 26 Januari hingga 27 Februari telah dilakukan penerbangan sebanyak 66 sorti penerbangan dengan rincian 44 sorti penerbangan menggunakan pesawat Hercules A-1323 dan 22 sorti penerbangan menggunakan ASA 212-200 U-616, dengan menghabiskan bahan semai sebanyak 201.8 ton (table 1).

Tabel 1. Jumlah bahan semai yang habis digunakan dengan pesawat terbang

\begin{tabular}{|l|l|l|l|}
\hline \multicolumn{1}{|c|}{ Pesawat } & (Register) & \multicolumn{1}{c|}{ Sorti } & \multicolumn{1}{c|}{$\begin{array}{c}\text { Bahan } \\
\text { Semai }\end{array}$} \\
\hline $\begin{array}{l}\text { Hercules C- } \\
130\end{array}$ & $\mathrm{~A}-1323$ & 44 & 181.5 ton \\
\hline Cassa & $\mathrm{U}-616$ & 22 & 20.3 ton \\
\hline
\end{tabular}

Daerah sasaran penerbangan (target operasi) adalah wilayah DKI Jakarta dan sekitarnya, seperti yang tergambarkan dalam Gambar 8. 


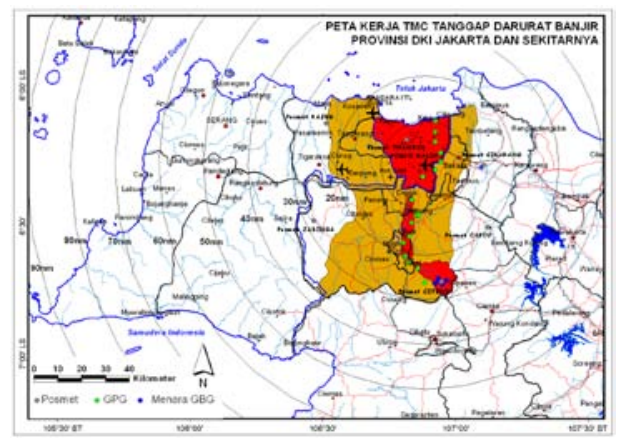

Gambar 8 Peta Wilayah Kerja TMC di Provinsi DKI Jakarta

Gambar 9 dan 10 menunjukkan realisasi track seeding selama kegiatan TMC periode 26 Januari hingga 27 Februari 2013.

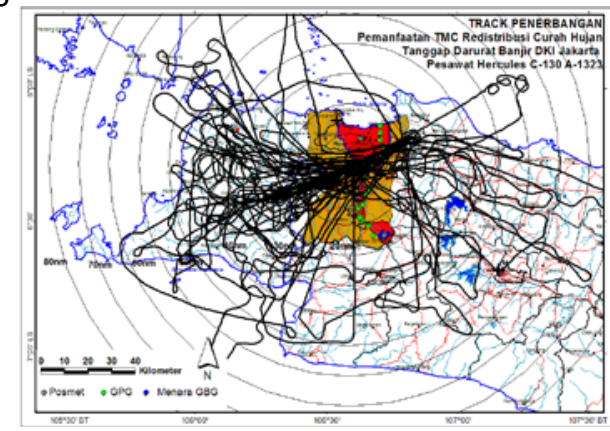

Gambar 9. Realisasi Akumulasi Track Seeding pesawat Hercules A-1323 selama kegiatan TMC tanggal 26 Januari 27 Februari 2013.

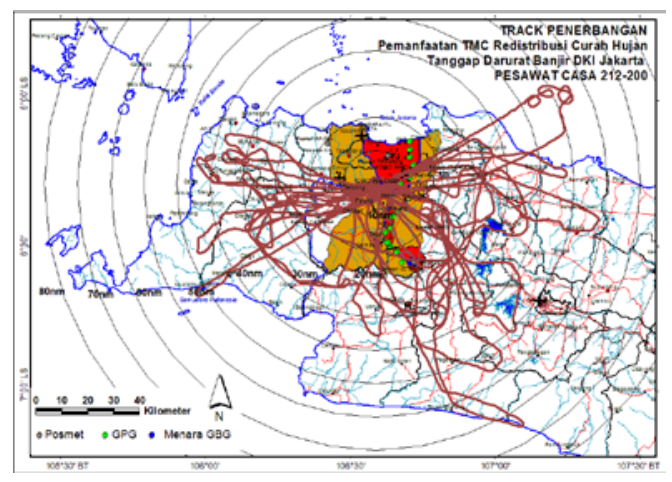

Gambar 10. Realisasi Akumulasi Track Seeding pesawat Casa 212-200 U-616 selama kegiatan TMC tanggal 26 Januari - 27 Februari 2013.

Pada kegiatan Pemanfaatan Teknologi Modifikasi Cuaca (TMC) untuk Redistribusi Curah
Hujan dalam Rangka Tanggap Darurat Banjir di Provinsi DKI Jakarta dan Sekitarnya Tahun 2013, dioperasikan sistem penyemaian dari darat di yang tersebar di wilayah Jabodetabek sebanyak 19 (tiga belas) titik stasiun. Nama - nama stasiun tersebut ditunjukkan pada table 2 .

Tabel 2. Nama stasiun

\begin{tabular}{|l|l|l|}
\hline No. & \multicolumn{1}{|c|}{ Nama Stasiun } & \multicolumn{1}{|c|}{ Keterangan } \\
\hline 1 & Sukapura - Jak Utara & GPG \\
\hline 2 & $\begin{array}{l}\text { BPPT Thamrin - Jak } \\
\text { Pusat }\end{array}$ & GPG \\
\hline 3 & Jatibening - Bekasi & GPG \\
\hline 4 & Jatibening - Bekasi & Pohon Flare \\
\hline 5 & Susukan - Jak Timur & GPG \\
\hline 6 & Susukan - Jak Timur & Pohon Flare \\
\hline 7 & Jatijajar - Depok Timur & GPG \\
\hline 8 & Tole Iskandar Depok & Pohon Flare \\
\hline 9 & Cibinong & Pohon Flare \\
\hline 10 & Ciluar & Pohon Flare \\
\hline 11 & Warung Jambu & Pohon Flare \\
\hline 12 & Pahlawan Bogor & GPG \\
\hline 13 & Cibolang - Gn Salak & GPG \\
\hline 14 & Tapos - Ciawi & Pohon Flare \\
\hline 15 & Tapos Caringin & GPG \\
\hline 16 & Citeko & Menara GBG \\
\hline 17 & Tugu & Menara GBG \\
\hline 18 & Pekancilan & Menara GBG \\
\hline 19 & Lemah Nendeut & Menara GBG \\
\hline
\end{tabular}

Peralatan TMC dari darat mulai dari GPG, pohon flare dan menara GBG pengoperasiaannya menunggu instruksi dari Posko Halim. Dalam kegiatan briefing harian yang dilakukan di posko Halim yang membahas materi persiapan penerbangan dan kondisi cuaca baik global dan lokal, akan diputuskan status kondisi terkait dengan penerbangan hari itu. Bila diketahui bahwa prediksi cuaca di Jabodetabek akan terjadi banyak pertumbuhan awan, maka posko Halim akan mengintruksikan kepada stasiun peralatan TMC darat untuk mengoperasional peralatannya.

Banyaknya CoSAT yang dinyalakan setiap hari baik di pohon flare dan menara GBG serta super hyggro liquid yang dibakar habis di GPG tampak pada table 3. 
Tabel 3. Bahan semai dan waktu penyalaan Pohon Flare, GBG dan GPG

\begin{tabular}{|c|c|c|c|}
\hline Bahan & $\begin{array}{c}\text { Pohon } \\
\text { Flare }\end{array}$ & $\begin{array}{c}\text { Menara } \\
\text { GBG }\end{array}$ & GPG \\
\hline CoSAT & 323 & 191 & - \\
\hline Liquid & - & - & $\begin{array}{c}175 \text { jam } \\
27 \text { menit }\end{array}$ \\
\hline
\end{tabular}

\section{Operasional Penyalaan Generator Partikel.}

GPG pada dasarnya adalah pembangkit partikel higroskopis yang sangat halus berukuran kurang dari 1 mikron. Dari pengukuran yang telah dilakukan sementara (dengan metoda dummy) tercatat distribusi puncak dominan pada ukuran 0,3 mikron sebanyak 150 juta partikel per $\mathrm{m}^{3}$. Sedangkan partikel dengan ukuran 0,5 mikron sebanyak 1,2 juta partikel per $\mathrm{m}^{3}$. Dari pengukuran yang telah dilakukan sementara (dengan metoda dummy) tercatat distribusi puncak dominan pada ukuran 0,3 mikron sebanyak 150 juta partikel per $\mathrm{m}^{3}$. Sementara itu partikel dengan ukuran 0,5 mikron sebanyak 1,2 juta partikel per $\mathrm{m}^{3}$. Dalam operasinya, tiap 1 jam bisa dibakar 1.5 liter larutan dengan partikel berbentuk nano cluster. Setiap hari GPG dioperasikan selama kurang lebih 6 jam.

\section{Operasional Menara Ground Base Generator (GBG)}

Selain mengoperasikan pohon flare (tree flare) dan ground particle generator (GPG) dalam kegiatan Pemanfaatan Teknologi Modifikasi Cuaca (TMC) untuk Redistribusi Curah Hujan dalam Rangka Tanggap Darurat Banjir di Provinsi DKI Jakarta dan Sekitarnya dioperasikan juga sebanyak 5 (lima) menara GBG yang tersebar di kawasan puncak perkebunan teh Gunung Mas Cisarua Kabupaten Bogor.

Fungsi dan tujuan pengoperasian menara GBG di kawasan puncak adalah untuk memberikan perlakuan pada awan-awan yang tumbuh di sekitar puncak gunung Gede Pangrango, dengan menggunakan bahan semai CoSat yang diletakkan pada puncak menara setinggi $50 \mathrm{~m}$ dari permukaan tanah sedangkan ketinggian lokasi menara berkisar antara 900 hingga $1100 \mathrm{~m}$ diatas permukaan laut. Dengan proses penyalaan CoSat akan mengeluarkan asap hasil pembakaran berupa asap yang mengandung partikel-partikel yang sangat kecil sekitar $2-5$ micron yang bergerak keatas oleh gaya angkat angin lembah menuju awan.

Partikel-partikel yang berukuran sangat kecil tersebut, setelah memasuki sistem awan akan memeberikan efek competisi pada sistem awan yang mengganggu pertumbuhan awan menjadi lebih tinggi lagi. Instruksi penyalaan CoSat diputuskan oleh Posko Halim disesuikan dengan perkembangan cuaca. Konstruksi menara GBG disajikan pada Gambar 11.

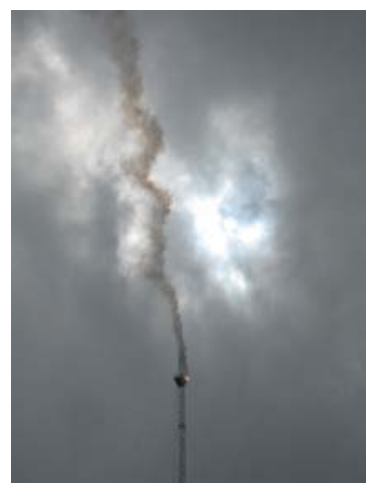

Gambar 11. Penyalaan CoSat di Menara Citeko

\section{Operasional Pohon Flare (Flare tree)}

Pohon flare (flare tree) yang dimaksud dalam kegiatan ini pada dasarnya adalah suatu peralatan yang berfungsi untuk melepaskan bahan semai berupa flare (CoSat) yang berada di pemukaan tanah. Bahan semai yang digunakan sama seperti pada menara GBG.

Setiap pohon flare mampu memuat sebanyak 12 unit Cosat. Sistem penyalaan CoSat juga sama dengan menara GBG, yaitu menggunakan Aki 12 volt yang terhubung dengan kabel ke masing-masing CoSat. Sistem kerja pohon flare ini juga hampir sama dengan menara GBG. Dengan proses penyalaan CoSat akan mengeluarkan asap hasil pembakaran berupa asap yang mengandung partikel-partikel yang sangat kecil sekitar $2-5$ mikron yang bergerak keatas oleh gaya angkat yang ditbangkitkan oleh proses konveksi yang berlangsung di sekitar lokasi pohon flare. Partikel-partikel yang berukuran sangat kecil tersebut, setelah memasuki sistem awan akan memeberikan efek competisi pada sistem awan yang mengganggu pertumbuhan awan menjadi lebih tinggi lagi. Instruksi penyalaan CoSat diputuskan oleh Posko Halim disesuikan dengan perkembangan cuaca. Sebaran lokasi menara GBG dijelaskan pada Gambar 8 dan konstruksi menara GBG disajikan pada Gambar 12 


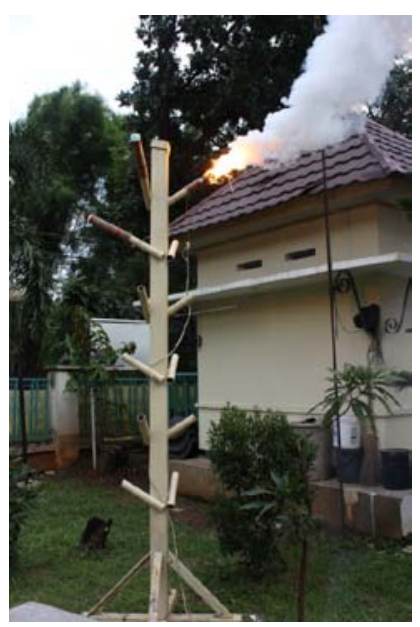

Gambar 12. Penyalaan CoSat di Pohon Flare

\subsubsection{Aktifitas di Pos Pengukuran Meteorologi}

Untuk melakukan monitoring kondisi cuaca lokal dan hasil survei serta pertimbangan tertentu telah diputuskan ada 6 (enam) lokasi posmet di Jabodetabek dan sekitarnya yaitu: (1) Posmet Citeko, Kabupaten Bogor; (2) Posmet Jasinga, Kabupaten Bogor; (3) Posmet Rajeg Kabupaten Tangerang (4) Posmet Cikarang Kabupaten Bekasi, (5) Posmet Cariu Kabupaten Bogor dan (6) Posmet Thamrin.

Seluruh posmet ini ini bertugas memantau kondisi cuaca yang dilakukan setiap jam mulai pukul 07.00 sampai dengan 17.00 WIB. Adapun aktifitas yang dilakukan oleh petugas posmet antara lain: pengukuran tekanan udara, pengukuran suhu bola basah, pengukuran suhu bola kering, suhu titik embun, kelembaban udara, dan pencatatan curah hujan.

Untuk mengoperasikan kegiatan di Posmet, UPT Hujan Buatan BPPT telah menempatkan 2 (dua) personil pengamat (Observer) Meteorologi pada setiap posmet. Petugas posmet tersebut bertugas sehari penuh mulai jam 06.30 WIB hingga jam 18:00 WIB selama operasi berlangsung. Pelaporan data posmet dilakukan setiap jam mulai jam 07.00 sampai dengan jam 17.00 WIB.

Hasil pengamatan dan informasi dari seluruh posmet yang di wilayah Jabodetabek ini selanjutnya dikaji dan dianalisis serta diinterpretasikan sebagai masukan pengambilan keputusan dalam mendukung analisis perkembangan cuaca lokal yang terkait dengan penerbangan penyemaian awan.

\section{HASIL}

\subsection{Curah Hujan Wilayah}

Untuk melihat kejadian hujan di daerah Jabodetabek pada umumnya dan DKI Jakarta khususnya, telah di pantau sebanyak 38 buah penakar hujan yang tersebar di seluruh wilayah Jabodetabek. Hasil pengukuran curah hujan dapat di lihat pada Gambar 13. Dari hasil pengukuran curah hujan, nampak bahwa di Jabodetabek dari tanggal 26 Januari sampai dengan 27 Februari 2013 , tiap hari terjadi hujan dengan variasi gerimis sampai lebat. Selama periode operasi TMC, hujan cukup besar dan merata terjadi pada tanggal 4 Februari, 6 Februari dan 12 Februari 2013, yaitu masing-masing sebesar $17,4 \mathrm{~mm}, 20,2 \mathrm{~mm}$ dan $38,8 \mathrm{~mm}$. Hal ini mengakibatkan adanya genangan bahkan ada beberapa sungai yang meluap yang mengakibatkan banjir sesaat.

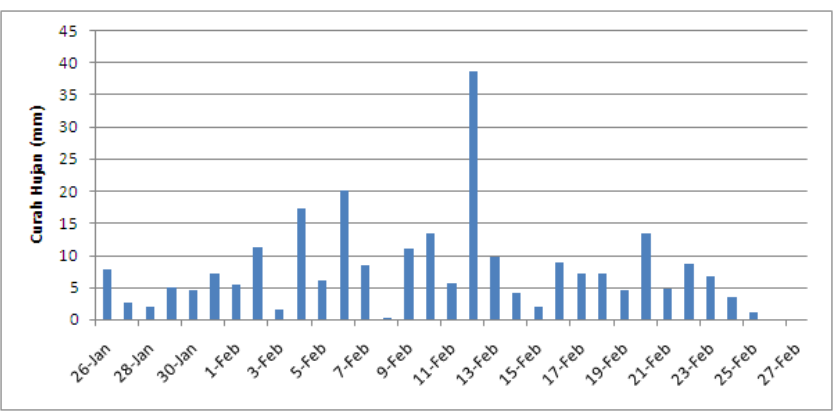

Gambar 13. Grafik curah hujan wilayah Jabodetabek selama TMC

Secara umum, curah hujan di wilayah Jabodetabek selama pelaksanaan TMC 26 Januari sampai dengan 27 Februari 2013 tidak terlalu besar, yaitu dibawah $10 \mathrm{~mm}$. Hujan-hujan seperti ini bahkan masih diharapkan terjadi, sehingga bisa digunakan untuk mengisi air tanah yang sangat diperlukan untuk kelestarian lingkungan.

\subsection{Analisis Hujan Harian Sebelum dan Selama Pelaksanaan TMC}

Untuk melihat potensi hujan, dilakukan prediksi hujan dengan menggunakan model GFS (Global Forecasting System), yang bisa memprediksi curah hujan harian selama seminggu kedepan. Curah hujan aktual 2013 didapatkan dengan menggunakan data satellite TRMM (Tropical Rainfall Measuring Mission) dan juga dengan memantau curah hujan yang terukur di 38 lokasi penakar hujan yang tersebar di seluruh 
wilayah Jabodetabek . Curah hujan historis yang digunakan di sini adalah data curah hujan TRMM dari tahun 2001 sampai dengan 2012.

Secara umum, untuk periode sebelum pelaksanaan TMC (1 sampai dengan 25 Januari 2013) curah hujan TRMM maupun curah hujan penakar aktual 2013 lebih besar dibandingkan dengan curah hujan hasil prediksi GFS maupun curah hujan TRMM historis pada periode yang sama. Sedangkan pada periode selama pelaksanaan TMC, secara umum terjadi sebaliknya, yaitu curah hujan TRMM maupun curah hujan penakar aktual lebih kecil dari curah hujan hasil prediksi GFS maupun curah hujan TRMM historis pada periode yang sama seperti terlihat pada Tabel 4.

Tabel 4. Akumulasi curah hujan TRMM historis, curah hujan TRMM aktual 2013, curah hujan penakar aktual 2013 dan prediksi curah hujan dengan model GFS, sebelum dan selama pelaksanaan TMC.

\begin{tabular}{|c|c|c|c|c|}
\hline PERROOE & $\begin{array}{c}\text { RERATA HISTORIS CH } \\
\text { TRMM 2001 - 2012 } \\
\text { (mm) }\end{array}$ & $\begin{array}{c}\text { PREDISKSI CH GFS 2013 } \\
\text { (mm) }\end{array}$ & $\begin{array}{c}\text { CH PENaKaR 2013 } \\
\text { (mm) }\end{array}$ & $\begin{array}{c}\text { CH TRMM } \\
\text { AKTUAL 2013 } \\
\text { (mm) }\end{array}$ \\
\hline $\begin{array}{c}\text { 01 s.d. 25 Januarl } \\
\text { (Sebelum TMC) }\end{array}$ & 271.25 & 351.00 & 414.11 & 420.99 \\
\hline $\begin{array}{c}\text { 26 Jan s.d 27 Februari } \\
\text { (Selama TMC) }\end{array}$ & 413.02 & 537.14 & 253.43 & 329.43 \\
\hline
\end{tabular}

Berdasarkan data diatas tingkat pengurangan curah hujan selama operasional TMC adalah sebagai berikut:

a. Pengurangan curah hujan terhadap historisnya:

o Berdasarkan data CH TRMM :

Pengurangan $\mathrm{CH}=(329.43 \mathrm{~mm}-413.02$

$\mathrm{mm}): 413.02 \mathrm{~mm} \times 100 \%$

$=-0.2024 \times 100 \%$

$=-20.24 \%$

- Berdasarkan data $\mathrm{CH}$ penakar:

Pengurangan $\mathrm{CH}=(253.43 \mathrm{~mm}-413.02$ $\mathrm{mm}): 413.02 \mathrm{~mm} \times 100 \%$

$=-0.3864 \times 100 \%$

$=-38.64 \%$

b. Pengurangan curah hujan terhadap hasil prediksi GFS:

o Berdasarkan data CH TRMM :

Pengurangan $\mathrm{CH}=(329.43 \mathrm{~mm}-537.14 \mathrm{~mm})$ :

$537.14 \mathrm{~mm} \times 100 \%$

$=-0.38669 \times 100 \%$

$=-38.67 \%$

- Berdasarkan data $\mathrm{CH}$ penakar:

Pengurangan $\mathrm{CH}=(253.43 \mathrm{~mm}-537.14$

$\mathrm{mm}): 537.14 \mathrm{~mm} \times 100 \%$

$=-0.5282 \times 100 \%$
$=-52.82 \%$

\section{PENUTUP}

\subsection{Ringkasan}

1. Selama berlangsungnya pelaksanaan TMC di Provinsi DKI Jakarta, total telah dilakukan 66 sorti penerbangan penyemaian dengan rincian 44 sorti penerbangan menggunakan pesawat Hercules A-1323 dan 22 sorti penerbangan menggunakan CASA 212-200 U-616. Total bahan semai $\mathrm{NaCl}$ powder yang ditaburkan di udara sebanyak 201,8 ton, sementara penyemaian awan dari darat dengan sistem Ground Base Generator (GBG) telah melakukan pembakaran 486 batang flare dari 14 lokasi GBG sistem flare dan GBG sistem larutan dari 9 lokasi masing-masing selama 158 jam.

2. Kondisi cuaca selama pelaksanaan TMC umumnya dipengaruhi oleh faktor global/regional yang normal. Temperatur muka laut di sekitar laut Jawa cukup hangat sehingga menunjang pembentukan awan hujan di DKI Jakarta dan sekitarnya. Angin secara umum berhembus dari barat sebagai pertanda musim hujan. Namun demikian pada pertengahan operasi TMC angin di Jakarta dan sekitarnya berhembus dari timur akibat pengaruh tekanan rendah di barat daya Jawa dengan tetap membawa uap air yang banyak. Curah hujan tinggi pada minggu kedua pelaksanaan TMC umumnya terjadi ketika angin berhembus dari timur.

3. Secara umum, untuk periode sebelum pelaksanaan TMC (1 s.d 25 Januari 2013) curah hujan TRMM (Tropical Rainfall Measurement Mission, pengukuran curah hujan menggunakan satelit) maupun curah hujan penakar aktual 2013 lebih besar dibandingkan dengan curah hujan hasil prediksi GFS (Global Forecasting System, model prediksi curah hujan dari NOAA) maupun curah hujan TRMM historis pada periode yang sama. Sedangkan pada periode selama pelaksanaan TMC, secara umum terjadi sebaliknya, yaitu curah hujan TRMM maupun curah hujan penakar aktual lebih kecil dari curah hujan hasil prediksi GFS maupun curah hujan TRMM historis pada periode yang sama.

4. Berdasarkan data curah hujan historis dari TRMM, curah hujan aktual dari penakar dan TRMM, serta prediksi curah hujan dari GFS diperoleh hasil perhitungan pengurangan 
curah hujan selama operasional TMC sebesar 20-50\%

5. Selama pelaksanaan TMC secara umum bencana banjir dapat diminimalisir. Tercatat 2 kali terjadi genangan akibat curah hujan yang tinggi tanggal 4 dan 12 Februari di daerah hulu dan sekali terjadi genangan di Jakarta akibat hujan tinggi tanggal 6 Februari di wilayah Jakarta.

\subsection{Saran}

1. Pelaksanaan Pemanfaatan Teknologi Modifikasi Cuaca (TMC) Untuk Redistribusi Curah Hujan Dalam Rangka Tanggap Darurat Banjir di Provinsi DKI Jakarta dan Sekitarnya Tahun 2013 yang telah berjalan dengan baik ini ke depan perlu dilakukan koordinasi awal yang lebih baik lagi agar semua pihak dapat berperan dengan lebih baik. Dukungan Badan Penanggulangan Bencana Daerah perlu lebih dioptimalkan.

2. Pelaksanaan TMC ini didesain sebagai operasi tanggap darurat banjir dimana semua pekerjaan difokuskan pada upaya untuk mengurangi potensi banjir yang mungkin terjadi. Ke depan, perlu dibuat desain yang juga mengakomoasi sisi ilmiahnya secara lebih baik, yaitu dibuatnya sebuah daerah control yang tidak diberi perlakuan penyemaian tetapi dilakukan pengamatan dan pengukuran secara intensif. Memang akan ada konsekuensi penambahan anggaran tetapi hasil pekerjaan bisa dipertanggungjawabkan secara lebih ilmiah di dunia internasional.

3. Untuk menghindari kerusakan pesawat (khususnya Hercules) akibat bahaya korosi, sebaiknya dilakukan rekayasa peralatan penunjang penyemaian yang lebih baik. Perlu dilakukan kerjasama antara BPPT, TNI, dan BNPB untuk menghasilkan system penyemaian yang aman dari bahaya korosi.

\section{DAFTAR PUSTAKA}

1. Givati, A. and D. Rosenfeld, 2004: Quantifying precipitation suppression due to air pollution, Journal of Applied Meteorology, 43, pp.1038-1056.

2. Hsu.C.F, Changnon Jr.S.A, Huff. F.A, and Gabriel K.R, 1981: The assessment of statistical - physical techniques for the evaluation of weather modification operations, State Water Survey Contract Report 286.

3. Khain et al, 2004: Simulation of Effects of Atmospheric Aerosols on Deep Turbulent Convective Clouds Using a Spectral Microphysics Mixed-Phase Cumulus Cloud Model. Part I: Model Description and Possible Applications, Journal of the Atmospheric Sciences, Vol. 61, pp.2963-2976.

4. Pinsky M., A. Khain, and M. Shapiro, 2000: Collision efficiency of drops in a wide range of Reynolds numbers: effects of pressure on spectrum evaluation, $\mathrm{J}$. Atmos. Sci., 58, pp. 742-764.

5. Yin, Y., Z. Levin, T. Reisin, and S. Tzivion, 2000: Seeding convective clouds with hygroscopic flares: Numerical simulations using a cloud model with detailed microphysics, Journal of Applied Meteorology.

\section{Ucapan Terima kasih}

1. Kepala BNPB, Bapak Dr. Syamsul Ma'arif, yang telah mempercayakan pelaksanaan kegiatan ini kepada UPT Hujan Buatan BPPT. Terimakasih juga disampaikan pada jajaran BNPB atas kerjasama yang baik selama pelaksanaan TMC di Provinsi DKI Jakarta dan sekitarnya.

2. Panglima TNI, Komandan Pangkalan Udara TNI-AU Halim Perdana Kusuma, Komandan Skuadron 31 TNI-AU Halim Perdana Kusuma, Komandan Skuadron 6 TNI-AL PUSPENERBAL Surabaya, atas dukungan pesawat dan fasilitas penerbangan lainnya.

3. Gubernur DKI Jakarta, Jawa Barat dan Banten beserta jajarannya, yang telah memberikan fasilitas dan kerjasama selama pelaksanaan TMC di wilayah Provinsi DKI Jakarta dan sekitarnya.

4. Kepala Bandara Pondok Cabe, yang telah mengijinkan penggunaan Bandara Pondok Cabe sebagai Posko Sekunder kegiatan TMC di Provinsi DKI Jakarta dan sekitarnya.

5. Jajaran Badan Meteorologi Klimatologi dan Geofisika yang telah membantu analisa cuaca selama pelaksanaan kegiatan TMC.

6. Semua pihak yang telah membantu dalam pelaksanaan Penerapan TMC di Provinsi DKI Jakarta dan sekitarnya. 